\title{
Literatura:
}

BALHAR, J. a kol.: Český jazykový atlas. 1. Praha: Academia, 1992. ISBN 978-80-86496$-67-2$.

BALHAR, J. a kol.: Český jazykový atlas. 2. Praha: Academia, 1997. ISBN 80-200-0574-9. BALHAR, J. a kol.: Český jazykový atlas. 3. Praha: Academia, 1999. ISBN 80-200-0654-0. BALHAR, J. a kol.: Český jazykový atlas. 4. Praha: Academia, 2002. ISBN 80-200-0921-3. BALHAR, J. a kol.: Český jazykový atlas. 5. Praha: Academia, 2005. ISBN 80-200-1339-3. BALHAR, J. a kol.: Český jazykový atlas. Dodatky. Praha: Academia, 2011. ISBN 978-80-200-1967-7.

KLOFEROVÁ, S.: Nářeční atlasy slovanských jazyků. Historie a současnost. Gwary Dziś, 2015, č. 7, s. 43-55.

Leksičeskij atlas russkich narodnych govorov (LARNG). Probnyj vypusk. Sankt-Peterburg: Nauka, 2004.

Leksičeskij atlas russkich narodnych govorov (LARNG): Tom 1. Rastitel'nyj mir. Moskva-Sankt-Peterburg: Nestor-Istorija, 2017.

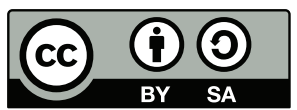

Toto dílo Ize užít v souladu s licenčními podmínkami Creative Commons BY-SA 4.0 International (<https:// creativecommons.org/licenses/by-sa/4.0/legalcode>). Uvedené se nevztahuje na díla či prvky (např. obrazovou či fotografickou dokumentaci), které jsou v díle užity na základě smluvní licence nebo výjimky či omezení př́slušných práv.

\section{Dvĕ nové monografie ze srovnávací slovanské jazykovědy}

СТОЙЧЕВ, С.: Българският морфологичен релатив и чешкият език или за съвременния български морфологичен релатив и неговите функционални еквиваленти в съвременния чешки език. София: Издателство „Силует“, 2019. 405 c. ISBN 978-619-194-054-7.

СТОЙЧЕВ, С.: Българският морфологичен резултатив и чешкият език или за съвременния български морфологичен резултатив и неговите функционални еквиваленти в съвременния чешки език. София: Издателство „Силует“, 2019. 356 с. ISBN 978-619-194-053-0.

V roce 2019 byla srovnávací slovanská jazykověda obohacena o dvě precizní výzkumné práce z oblasti srovnávací slovanské morfologie. Jejich autorem je dr. Stilijan Stojčev, 
bohemista ze Sofijské univerzity sv. Klimenta Ochridského. První se v překladu jmenuje Bulharský morfologický rezultativ a čeština neboli O současném bulharském morfologickém rezultativu a jeho funkčních ekvivalentech v současné češtině, druhá Bulharský morfologický relativ a jeho funkční ekvivalenty v současné češtině.

To, co na první pohled spojuje obě monografie, svým objemem velice respektuhodné, je detailní analýza asymetrie mezi českým a bulharským jazykem projevující se v určitých morfologických kategoriích (rezultativ a relativ), přičemž obě jsou představeny vyčerpávajícím způsobem podpořeným znamenitou orientací v existující odborné literatuře k tématu, a to nejen bulharské nebo české, ale i v celoslovanském kontextu, obě vykazují přesně zvolenou metodologii a v neposlední řadě vysokou terminologickou preciznost. Ve slovanské jazykovědě byly morfologický rezultativ a relativ kontrastivně představeny v takové teoretické hloubce vůbec poprvé, přičemž autor uvádí svá argumentačně podpořená stanoviska, $\mathrm{v}$ nichž poukazuje na shody a rozdíly mezi oběma zkoumanými jazyky. Je třeba poznamenat, že obě publikace třebaže se ve své podstatě jedná o teoretické gramatické studie par excellence - mohou posloužit též současným i budoucím překladatelům mezi češtinou a bulharštinou, jelikož detailně popisují mj. problémy překladových ekvivalentů výše uvedených morfologických kategorií, které se mohou realizovat jak v čistě morfologickém, tak i v lexikálním, syntaktickém a dokonce i textovém plánu. Právě odhalování cizojazyčné funkční ekvivalence představuje hlavní přínos obou monografií - a to jak v čistě teoretickém aspektu, tak i z hlediska jazykové pragmatiky. Zajímavé a nesporně novátorské jsou Stojčevovy poznatky ohledně vnitřní jazykové funkční ekvivalence a vzájemné zaměnitelnosti zkoumaných kategorií.

Monografie Българският морфологичен релатив и чешкият език s podtitulem $3 a$ съвременния български морфологичен релатив и неговите функционални еквиваленти в съвременния чешки език (O současném bulharském morfologickém rezultativu a jeho funkčních ekvivalentech v současné češtině) odkazují ke kontrastivnímu výzkumu současné bulharštiny a češtiny, tj. $\mathrm{k}$ jazykové synchronii. Tato preference současného stavu obou slovanských jazyků byla do jisté míry motivována i přáním autora, aby výsledky jeho výzkumu měly nejen teoretickou, ale i aplikovatelnou hodnotu. Objektem výzkumu v této publikaci jsou jak projevy konkurence mezi jednotlivými jazykovými prostř̌edky při explikaci sému relativity $\mathrm{v}$ bulharštině a češtině, tak i gramatické asymetrie mezi nimi v tomto ohledu. St. Stojčev zkoumá na straně jedné bulharské finitní slovesné tvary, tj. tvary prríznakového gramému relativ bulharské slovesné kategorie relativity (taxisu) jakožto centrálního morfologického prostředku vyjádření sému relativity, a na straně druhé hledá jejich funkční ekvivalenty v současné bulharštině i současné češtině. Kromě synchronní analýzy morfologického relativu autor přináší nejen výčet, ale také klasifikaci zjištěných funkčních ekvivalentů. Zevrubně autor představuje bulharskou morfologickou kategorii relativity (taxisu) 
v dějinách bulharského spisovného jazyka, určuje místo této kategorie v gramatickém systému současné bulharštiny a dává i vyčerpávající odpovědi na otázku, zda a do jaké míry současná čeština zná kategorii typu bulharské kategorie taxisu (relativity). Zároveň autor konfrontuje bulharský relativ a jeho bulharské i české funkční ekvivalenty v rámci ostatních kategorií příznačných pro bulharská slovesa. Př́nosem autorova výzkumu je také zjištění, že bulharský empirický materiál dokládá další aspekty slovesné relativity, nejen aspekt temporální, což znamená, že slovesná relativita se nepřekrývá se slovesnou temporálností, což potvrzuje tezi o samostatné kategoriální povaze relativity v současné bulharštině. Nutno dodat, že autor velice fundovaně používá různé metody při analýze jazykového materiálu - jak metody analytické (metoda sémaziologická, metoda onomaziologická, metoda morfematické analýzy, metoda komponentové analýzy a synchronní kontrastivní metoda), tak i např. metodu zjištování funkční ekvivalence a při zjištování českých funkčních ekvivalentů bulharského morfologického relativu použil i metody korpusové kontrastivní lingvistiky a metodu zjištování cizojazyčné funkční ekvivalence. Analyzovaný jazykový materiál je velmi bohatý - empirický materiál byl z větši části excerpován z paralelních bulharských a českých textů zařazených do Paralelního korpusu InterCorp Českého národního korpusu.

Druhá monografie Българският морфологичен резултатив и чешкият език s podtitulem За съвременния български морфологичен резултатив и неговите функиионални еквиваленти в съвременния чешки език (O současném bulharském morfologickém relativu a jeho funkčních ekvivalentech $v$ současné češtině) se věnuje současnému bulharskému morfologickému rezultativu a představuje autorovu koncepci o podstatě morfologického rezultativu jakožto př́íznakového gramému rezultativ dvougramémové slovesné morfologické kategorie typ děje a jeho postavení v gramatickém systému současné bulharštiny, v syntagmatickém a paradigmatickém plánu a také o jeho postavení ve funkčně-sémantickém mikropoli rezultativnosti v současné bulharštině. Autor ve svém výzkumu předkládá návrh modelu bulharského rezultativního funkčně-sémantického mikropole a zároveň zkoumá české funkční ekvivalenty bulharského morfologického indikativního rezultativu. Současně s tím konstruuje tzv. funkčně ekvivalentní vějíře zjištěných českých funkčních ekvivalentů bulharského morfologického rezultativu. Výsledky této synchronní kontrastivní analýzy prezentují řadu bulharských aktivních a pasivních indikativních rezultativních tvarů a jejich české funkční ekvivalenty. Prezentovaná modelovaná funkčně-sémantická mikropole rezultativnost jsou přesvědčivým př́kladem projevu nejen bulharsko-české mezijazykové asymetrie, ale také mezijazykové asymetrie vůbec. Značným př́nosem této monografie je to, že představuje první pokus v bulharistice a bohemistice uplatnit metody stanovení cizojazyčné funkční ekvivalence při zkoumání rezultativnosti v bulharštině a češtině. 
Obě monografie - jak ve své úplnosti, tak i jejich jednotlivé části - mohou být úspěšně použity i v procesu výuky bulharského jazyka pro Čechy, resp. českého jazyka pro Bulhary, a to nejen během prrípravy budoucích vyučujících, ale i při samotné výuce praktické češtiny, resp. bulharštiny, neboť sledované morfologické kategorie rezultativ i relativ, jejichž osvojování ze strany Slovanů učících se jiný slovanský jazyk je pouze zdánlivě snadné, představují komplexně - stylově vysokým, avšak srozumitelným odborným jazykem. Uvedené monografie poskytují úplný obraz o jejich podstatě a možném užívání.

Elena Krejčová

\section{Literatura:}

STOJČEV, S.: Bălgarskijat morfologičen relativi češkijat ezik ili za săvremennija bălgarski morfologičen relativ i negovite funkcionalni ekvivalenti $v$ săvremennija češki ezik. Sofija: Izdatelstvo „Siluet“, 2019. ISBN 978-619-194-054-7.

STOJČEV, S.: Bălgarskijat morfologičen rezultativ $i$ češkijat ezik ili za săvremennija bălgarski morfologičen rezultativ i negovite funkcionalni ekvivalenti $v$ săvremennija češki ezik. Sofija: Izdatelstvo „Siluet“, 2019. ISBN 978-619-194-053-0.

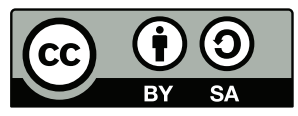

Toto dílo Ize užít v souladu s licenčními podmínkami Creative Commons BY-SA 4.0 International (<https:// creativecommons.org/licenses/by-sa/4.0/legalcode>). Uvedené se nevztahuje na díla či prvky (např. obrazovou či fotografickou dokumentaci), které jsou v díle užity na základě smluvní licence nebo výjimky či omezení príslušných práv.

\section{Bezpečnost silničního provozu v jazykovém obrazu světa dětí a mládeže}

WOJCIECHOWSKA, J.: Bezpieczeństwo drogowe w językowym obrazie świata dzieci i młodzieży. Bielsko-Biała: Wydawnictwo Naukowe ATH, 2018, $182 \mathrm{~s}$.

V roce 2018 vyšla v Polsku monografie Justyny Wojciechowské Bezpečnost silničního provozu v jazykovém obrazu světa dětí a mládeže - svým charakterem novátorská studie sjednocující úsilí jazykovědce a orgánů policie. Výsledkem této spolupráce je dílo, svým charakterem interdisciplinární, které je už proto neobyčejně pozoruhodné.

Ve svém výzkumu se autorka odvolává na mezinárodní dokumenty Evropského parlamentu a polské vlády, avšak - jak sama zdůrazňuje - klíčem k pochopení 